\title{
Przedsiębiorczość w szkole średniej w warunkach reformy systemu oświaty
}

DOI: 10.47050/65591760.184-202

Wioletta Kilar, Tomasz Rachwał

W rozdziale przedstawiono wyniki analizy zapisów nowej podstawy programowej kształcenia ogólnego dla szkół średnich w zakresie podstaw przedsiębiorczości na tle dotychczas obowiązującej podstawy. Wskazano na podobieństwa w zakresie liczby godzin przeznaczonych na realizację tego przedmiotu i na zasadnicze różnice w zakresie zapisów celów kształcenia - wymogów ogólnych, które w nowej podstawie zostały zapisane bardziej recyzyjnie i podzielone na trzy kategorie: w zakresie wiedzy, umiejętności i kształtowania postaw. W drugiej części pracy określono różnice i podobieństwa w zakresie podziału treści kształcenia na działy oraz zmiany w zakresie zapisów wymagań szczegółowych, kładąc szczególny nacisk na efekty kształcenia określane jako „innowacyjne”.

\section{Słowa kluczowe:}

edukacja w zakresie przedsiębiorczości

innowacyjne treści kształcenia

podstawa programowa

postawa przedsiębiorcza

reforma oświaty

szkoła średnia 


\section{Entrepreneurship in secondary school and educational system reform}

DOI: 10.47050/65591760.184-202

Wioletta Kilar, Tomasz Rachwał

The chapter presents the results of the analysis of the new core curriculum of general education for secondary schools in the field of entrepreneurship in the context of the current curriculum. The similarities in the number of hours allocated for this subject and the fundamental differences in the scope of learning objectives - general requirements, which in the new basis have been written more concretely and divided into three categories: in terms of knowledge, skills and attitudes, were pointed out. The second part of paper identifies the differences and similarities in the division of educational content into sections and changes in the scope of specific requirements, placing particular emphasis on learning outcomes referred to as "innovative".

Keywords:

education in the field of entrepreneurship

innovative content of education

core curriculum

entrepreneurial attitude

education reform

high school 


\section{Wstęp}

Szybko zmieniająca się otoczenie społeczno-gospodarcze w wyniku przechodzenia z industrialnej przez postindustrialną do informacyjnej fazy rozwoju cywilizacyjnego oraz budowy gospodarki opartej na wiedzy, stwarza nowe uwarunkowania funkcjonowania człowieka na rynku pracy i w życiu prywatnym. Wyzwaniem zarówno dla młodzieży, jak i osób dorosłych jest nie tylko umiejętność odnalezienia się w tej podlegającej dynamicznym przemianom rzeczywistości, ale także konkurowania na rynku międzynarodowym. Wynika to z nasilającej się presji konkurencyjnej, u podstaw której leży liberalizacja przepisów w zakresie przepływu zasobów pracy, towarów, usług i kapitału. Ponadto wiele regionów i państw świata, także Europy dotykają różnego typu kryzysy polityczne, społeczne i gospodarcze, co powoduje, że funkcjonujemy $w$ turbulentnych warunkach otoczenia.

Czynnikiem sprzyjającym przygotowaniu do życia w tych nowych, zmieniających się uwarunkowaniach jest dobre wykształcenie, szczególnie w zakresie tych umiejętności i postaw, które stanowią bazę dla funkcjonowania i współdziałania w życiu prywatnym i zawodowym. Szczególnie ważne jest tu kształcenie w zakresie przedsiębiorczości, która w szerokim rozumieniu tego pojęcia, jest obecnie jedną z fundamentalnych kompetencji każdego człowieka, na co wskazuje wielu autorów (Borowiec-Gabryś, Kilar, Rachwał 2018, Kalita 2014, Piróg 2015, Rachwał i in. 2018, Wach 2013, 2014).

Przedsiębiorczość, jako jedna z tzw. kompetencji kluczowych (Kompetencje kluczowe... 2005), jest konieczna by odnaleźć się we współczesnym, szybko zmieniającym się i bardzo często turbulentnym świecie. Jej kształtowaniu w znacznym stopniu sprzyja edukacja w zakresie przedsiębiorczości od jak najniższych etapów kształcenia, której głównym celem jest przygotowanie młodych ludzi do aktywnego i świadomego uczestnictwa w życiu społeczno-gospodarczym, do wykorzystywania szans obecnych w otoczeniu i podejmowania kreatywnych (innowacyjnych) działań lub projektów oraz do ewentualnego podjęcia własnej działalności gospodarczej. Stanowi to poważne wyzwanie dla osób odpowiedzialnych za system edukacji, w szczególności za jej aspekt programowy. Niezbędna jest bowiem systematyczna modernizacja programów kształcenia w zakresie celów, zakresu treści i stosowanych metod, aby sprostać tym wyzwaniom i zapotrzebowaniu w zakresie edukacji. 
W świetle tych przesłanek celem pracy jest przedstawienie wyników analizy zapisów nowej podstawy programowej w zakresie przedsiębiorczości dla szkół średnich w związku z wdrażaną reformą systemu oświaty w Polsce. W szczególności dokonano porównania działów (grup treści kształcenia), realizowanych lub zaplanowanych do realizacji w ramach przedmiotu podstawy przedsiębiorczości, które zostały zapisane w starej (z 2012 r.) i nowej (z 2018 r.) podstawie programowej, a także przyjętych celów ogólnych oraz szczegółowych. W pracy zmierzać się będzie również do wskazania innowacyjnych treści kształcenia i umiejętności, które zostały wprowadzone do nowej podstawy programowej w ramach reformy edukacji w Polsce w kontekście wyzwań cywilizacyjnych XXI w. Analizie poddano zapisy starych i nowych podstaw programowych dla liceum ogólnokształcącego, technikum oraz szkół branżowych I stopnia, dotychczas szkół zawodowych (Rozporzq̨dzenie MEN 2012, 2018a, b). Rozważania oparte są na wynikach prowadzonych badań przy wykorzystaniu kilku podstawowych metod tj. kwerendy i analizy literatury przedmiotu oraz analizy treści i analizy danych zastanych (desk research).

\section{Kształcenie w zakresie przedsiębiorczości w Polsce w świetle literatury przedmiotu}

Problematyka kształcenia w zakresie przedsiębiorczości podejmowana jest szeroko zarówno w literaturze krajowej, jak i zagranicznej. Autorzy koncentrujący się na procesie edukacji w tym zakresie w Polsce, pośród różnych zagadnień podkreślają między innymi potrzebę rozszerzania wiedzy i umiejętności w zakresie przedsiębiorczości u młodych ludzi na niższych niż uniwersytecki poziomach kształcenia. Upatrują w tym procesie możliwości zrozumienia i właściwej reakcji na szybko zmieniające się uwarunkowania społeczno-gospodarcze, w których współcześnie dorastają i będą w przyszłości funkcjonowali dzisiejsi uczniowie (Zioło 2009, 2012, Borowiec, Rachwał 2011). Wskazują także na konieczność zwrócenia większej uwagi na umiejętności i postawy związane z przedsiębiorczością, gdyż w warunkach polskich przez wiele lat w edukacji na poziomie średnim (gimnazjum i szkoła ponadgimnajzalna) dominowało wyposażenie uczniów w wiedzę ekonomiczną (Rachwał, Kurek, Boguś 2016). Podejmowano także problematykę kryteriów doboru celów i treści nauczania do podstawy programowej i programu nauczania 
z podstaw przedsiębiorczości (Rachwał 2004, Tracz 2005), statusu, miejsca, roli i rangi przedsiębiorczości w edukacji (Brzozowski 2013, Kawecki 2005, Tracz 2006, Zioło 2012) oraz analizy wyników badań opinii uczniów, nauczycieli i rodziców na temat realizacji przedmiotu podstawy przedsiębiorczości (Osuch E., Osuch W. 2006, Osuch 2012, Sowislok 2012, Ziółkowska-Weiss 2014, 2016). Ważnym przedmiotem badań było także przygotowanie nauczycieli tego przedmiotu (Tracz, Rachwał 2007), ich skuteczność jako wychowawców (Czechowski 2014) oraz stosowane przez nich metody nauczania i wykorzystywane środki dydaktyczne (Gaweł 2014, Kilar i in 2016, Kulikowska, Krasnodębska 2007, Łazowska 2005, Śrutowska 2006, Tracz, Rachwał 2008, Żur 2014).

W sytuacji ciągłych zmian w gospodarce i uwarunkowań prawnych podejmowania pracy najemnej i prowadzenia działalności gospodarczej, naturalnym przedmiotem zainteresowania badaczy są podejmowane próby zmian podstaw programowych kształcenia w zakresie przedmiotu (np. Górz, Rachwał 2006, Rachwał 2006, 2009, 2017, Wach 2012). Przedstawiano także propozycje nowej podstawy programowej w zakresie rozszerzonym (Rachwał i in. 2008), co dawałoby możliwość wprowadzenia podstaw przedsiębiorczości jako przedmiotu maturalnego do wyboru (Bartoń 2005). Podejmowana była także problematyka metod badań edukacji przedsiębiorczej (2016) oraz analizy bibliometrycznej polskiego piśmiennictwa odnoszącego się do edukacji w zakresie przedsiębiorczości (Wach 2016).

\section{Miejsce przedsiębiorczości w polskim systemie edukacji}

Edukacja w zakresie przedsiębiorczości w polskim systemie edukacji jest ważnym elementem kształcenia, choć nie ma to bezpośredniego odzwierciedlenia w liczbie godzin na realizację przedmiotu podstawy przedsiębiorczości. Oprócz tego, że pomaga zrozumieć otaczający młodego człowieka świat, na podkreślenie zasługuje fakt, że jest jedynym przedmiotem szkolnym w zakresie edukacji ekonomicznej młodzieży w Polsce. Zatem daje podstawy wiedzy i umiejętności z zakresu podstaw ekonomii, finansów, a także przygotowania do pracy zawodowej, w tym zakładania własnego biznesu.

Przedsiębiorczość, jako oddzielny obowiązkowy przedmiot szkolny został wprowadzony do szkół ponadgimnazjalnych w roku szkolnym 2002/2003, pod nazwą podstawy przedsiębiorczości. Była to decyzja 
podjęta w trakcie reformy, której wdrażanie rozpoczęto w 1999 r. Początkowo w ramach kształcenia ogólnego przedmiot był realizowany podczas dwóch godzin tygodniowo i w zależności od decyzji szkoły mógł być nauczany w jednej klasie (1 rok) w wymiarze dwóch godzin lub przez dwa lata w wymiarze 1 godz. tygodniowo.

Podczas kolejnej reformy z 2008 r. podtrzymano założenia, że podstawy przedsiębiorczości, jako obowiązkowy przedmiot szkolny, realizowane były w cyklu 60 godz. (1 klasa, 2 godz. tygodniowo). Jednocześnie na III etapie edukacyjnym, czyli w gimnazjum, część treści z zakresu podstaw przedsiębiorczości została wpisana również do podstawy programowej z wiedzy o społeczeństwie. Równolegle wprowadzono fakultatywny przedmiot szkolny ekonomia w praktyce, który według założeń był ściśle powiązany z podstawami przedsiębiorczości (Borowiec-Gabryś, Kilar, Rachwał 2018).

W założeniach obecnej, tj. wdrażanej od 2017 r. reformy, podtrzymana została liczba godzin w całym cyklu kształcenia, natomiast przedmiot ten będzie realizowany w drugiej i trzeciej klasie liceum i technikum oraz w pierwszej klasie szkoły branżowej I stopnia (Rozporzq̨dzenie MEN..., 2017). W szkołach policealnych będzie realizowany tylko w sytuacji, gdy uczniowie nie mieli go na niższych poziomach edukacji. Natomiast dotychczasowy przedmiot fakultatywny ekonomia w praktyce, nie występuje już w ofercie przedmiotów do wyboru. $\mathrm{Na}$ wcześniejszym etapie edukacyjnym, tj. w szkole podstawowej, w niewielkim zakresie treści dotyczące przedsiębiorczości realizowane są na wiedzy o społeczeństwie oraz jednostkowo na innych przedmiotach (zobacz jeden z wcześniejszych rozdziałów autorstwa W. Kilar i T.Rachwała oraz Kilar i in. 2018). Co istotne, w nowej podstawie programowej z podstaw przedsiębiorczości dla szkół ponadpodstawowych (zgodnie z harmonogramem wdrażania reformy będzie obowiązywać od roku szkolnego 2019/2020) przyjęto, że jednym z głównych celów dydaktycznych przedmiotu jest przygotowanie uczniów do planowania swojej przyszłości oraz do aktywności zawodowej w roli pracowników najemnych lub osób prowadzących własną działalność gospodarczą. Ma to sprzyjać przygotowaniu uczniów do aktywności społecznej i gospodarczej, a także do życia rodzinnego w znaczeniu ekonomicznym, dając podstawowe umiejętności konkurencyjnych zachowań na rynku, w tym ponoszenia konsekwencji swoich decyzji (Rozporzq̨dzenie MEN... 2018, Kilar i in. 2018). 


\section{Zmiany w podstawie programowej dla szkół średnich}

W nowej podstawie programowej utrzymano dotychczasową formę zapisu, na którą składają się:

$\rightarrow$ wstęp, w którym uzasadniono cele realizacji przedmiotu,

$\rightarrow$ cele kształcenia - wymagania ogólne, czyli podstawowe cele, jakie $w$ toku edukacji powinno się osiągnąć,

$\rightarrow$ treści nauczania - wymagania szczegółowe, które w sposób możliwie precyzyjny podają jakie treści powinny być realizowane i jakie efekty kształcenia osiągnięte,

$\rightarrow$ warunki realizacji w szkole.

Tak jak w poprzedniej podstawie programowej utrzymano styl zapisów wymagań szczegółowych w "języku efektów kształcenia", jak to jest powszechnie stosowane w krajach Unii Europejskiej. Stanowi to $z$ jednej strony pewne ograniczenie $w$ zakresie możliwości ogólnego sformułowania wymagania, ale z drugiej strony dzięki temu zapisy precyzyjnie wyrażają, co nauczyciel ma osiągnąć z uczniami.

W świetle przyjętej koncepcji przedmiot podstawy przedsiębiorczości stanowi zatem syntezę wybranych celowo elementów wiedzy z zakresu ekonomii, zarządzania i finansów, wzbogaconej elementami geografii społeczno-ekonomicznej, politologii, socjologii, psychologii oraz prawa. W ramach lekcji podstaw przedsiębiorczości uczniowie zapoznają się z podstawowymi kategoriami, mechanizmami i procesami ekonomicznymi oraz ich uwarunkowaniami instytucjonalnymi, behawioralnymi, kulturowymi i rynkowymi. Postawy przedsiębiorcze i wspierające je umiejętności powinny zatem pośrednio z tej wiedzy wynikać. W procesie kształcenia uczniowie dowiadują się, jak - realizując indywidualne cele ekonomiczne - być przedsiębiorczym, a zarazem społecznie odpowiedzialnym w swoich dążeniach i działaniach (Rozporzq̨dzenie MEN... 2018).

\section{Cele ksztalcenia w podstawach}

\section{programowych dla szkól średnich}

W stosunku do podstawy programowej dotychczas obowiązującej nastąpiła znaczna zmiana układu treści ogólnych celów kształcenia (Tabela 1). Dotychczas bowiem miały one nieco odmienny charakter, gdyż w wymaganiach ogólnych wyróżniono działy grupujące treści kształcenia: komunikacja i podejmowanie decyzji, gospodarka i przedsiębior- 
stwo, planowanie i kariera zawodowa oraz ostatni - zasady etyczne. Dotychczas cele ogólne zapisane były łącznie dla różnych kategorii. Jednak, ze względu na specyfikę przedmiotu korzystniejsze wydaje się, podzielenie celów ogólnych na kategorie: wiedza, umiejętności i stosowanie wiedzy w praktyce oraz kształtowanie postaw, jak to zapisano w nowej podstawie programowej. Zastosowane ujęcie podkreśla, często pomijaną, rolę umiejętności oraz postaw w kształceniu i codziennym życiu młodego człowieka, na co wcześniej zwracał uwagę m.in. T. Rachwał $(2005,2006)$. Podobny sposób zapisu został przyjęty m.in. w podstawie programowej z geografii (Rozporzq̨dzenie MEN... 2018a, Szkurłat i in. 2018).

Tabela 1. Cele kształcenia - wymagania ogólne w starej i nowej podstawie programowej

\begin{tabular}{|c|c|}
\hline NOWA PODSTAWA PROGRAMOWA DO SZKÓ $\leq$ ŚREDNICH* & $\begin{array}{l}\text { STARA PODSTAWA PROGRAMOWA DO SZKÓ } t \\
\text { ŚREDNICH** }\end{array}$ \\
\hline \multicolumn{2}{|c|}{ I. WIEDZA. } \\
\hline $\begin{array}{l}\text { 1. Poznanie elementarnych pojęć z zakresu podstaw } \\
\text { przedsiębiorczości. }\end{array}$ & nie występuje \\
\hline $\begin{array}{l}\text { 2. Rozumienie istoty przedsiębiorczości oraz pozna- } \\
\text { nie jej roli w gospodarce i życiu człowieka. }\end{array}$ & nie występuje \\
\hline $\begin{array}{l}\text { 3. Wyjaśnianie mechanizmów funkcjonowania go- } \\
\text { spodarki rynkowej, powiązań między jej podmiotami } \\
\text { oraz poznanie roli państwa w procesach gospodar- } \\
\text { czych. }\end{array}$ & $\begin{array}{l}\text { [Uczeń] charakteryzuje mechanizmy } \\
\text { funkcjonowania gospodarki i instytucji } \\
\text { rynkowych oraz rolę państwa w gospo- } \\
\text { darce. }\end{array}$ \\
\hline $\begin{array}{l}\text { 4. Zaznajomienie się z prawami i instytucjami chro- } \\
\text { niącymi konsumenta. }\end{array}$ & nie występuje \\
\hline $\begin{array}{l}\text { 5. Rozumienie roli pieniądza, rynków i instytucji } \\
\text { finansowych w gospodarce, funkcjonowaniu przed- } \\
\text { siębiorstw i życiu człowieka. }\end{array}$ & nie występuje \\
\hline $\begin{array}{l}\text { 6. Poznanie rodzajów podatków, ich wpływu na } \\
\text { budżety państwa, przedsiębiorstw i gospodarstw } \\
\text { domowych. }\end{array}$ & nie występuje \\
\hline $\begin{array}{l}\text { 7. Dostrzeganie znaczenia ubezpieczeń w działalno- } \\
\text { ści gospodarczej i życiu człowieka. }\end{array}$ & nie występuje \\
\hline $\begin{array}{l}\text { 8. Rozumienie funkcjonowania rynku pracy, zasad } \\
\text { aktywnego poszukiwania pracy, przygotowania się } \\
\text { do rozmowy kwalifikacyjnej, poznanie praw oraz } \\
\text { obowiązków pracownika i pracodawcy. }\end{array}$ & nie występuje \\
\hline
\end{tabular}




\begin{tabular}{|c|c|}
\hline $\begin{array}{l}\text { 9. Poznanie zasad funkcjonowania przedsiębiorstwa } \\
\text { w gospodarce rynkowej, form organizacyjno-praw- } \\
\text { nych, innowacyjnych modeli biznesowych i procedu- } \\
\text { ry rejestracji działalności gospodarczej. }\end{array}$ & $\begin{array}{l}\text { [Uczeń] wyjaśnia zasady funkcjonowa- } \\
\text { nia przedsiębiorstwa i sporządza prosty } \\
\text { biznesplan. }\end{array}$ \\
\hline $\begin{array}{l}\text { 10. Rozumienie zasad zarządzania, roli marketingu } \\
\text { oraz społecznej odpowiedzialności w funkcjonowa- } \\
\text { niu przedsiębiorstwa. }\end{array}$ & nie występuje \\
\hline \multicolumn{2}{|c|}{ II. UMIEJĘTNOŚCI I STOSOWANIE WIEDZY W PRAKTYCE. } \\
\hline $\begin{array}{l}\text { 1. Wyszukiwanie informacji z różnych źródeł, ich } \\
\text { selekcja i analizowanie. }\end{array}$ & nie występuje \\
\hline $\begin{array}{l}\text { 2. Stosowanie w praktyce kluczowych pojęć związa- } \\
\text { nych z przedsiębiorczością. }\end{array}$ & nie występuje \\
\hline $\begin{array}{l}\text { 4. Odpowiedzialne gospodarowanie pieniędzmi, } \\
\text { analizowanie, ocenianie i świadome korzystanie } \\
\text { z usług finansowych oraz inwestowanie kapitału } \\
\text { z wykorzystaniem wiedzy na temat praw klienta } \\
\text { usług finansowych. }\end{array}$ & $\begin{array}{l}\text { [Uczeń] rozróżnia i porównuje formy inwe- } \\
\text { stowania i wynikające z nich ryzyko. }\end{array}$ \\
\hline $\begin{array}{l}\text { 5. Podejmowanie niezależnych, odpowiedzialnych } \\
\text { decyzji finansowych w odniesieniu do własnych } \\
\text { zasobów. }\end{array}$ & nie występuje \\
\hline $\begin{array}{l}\text { 6. Podnoszenie kompetencji osobistych i społecz- } \\
\text { nych niezbędnych na rynku pracy oraz wzmacnianie } \\
\text { motywacji do pracy. }\end{array}$ & nie występuje \\
\hline $\begin{array}{l}\text { 7. Analizowanie oferty rynku pracy, sporządzanie } \\
\text { dokumentów aplikacyjnych, dokonywanie autopre- } \\
\text { zentacji oraz korzystne prezentowanie się podczas } \\
\text { rozmowy kwalifikacyjnej. }\end{array}$ & $\begin{array}{l}\text { [Uczeń] opisuje mocne strony swojej oso- } \\
\text { bowości; analizuje dostępność rynku pracy } \\
\text { w odniesieniu do własnych kompetencji } \\
\text { i planów zawodowych. }\end{array}$ \\
\hline $\begin{array}{l}\text { 8. Rozróżnianie skutków wynikających z nawiązania } \\
\text { i rozwiązania stosunku pracy oraz wykonywania } \\
\text { czynności na podstawie umów cywilnoprawnych } \\
\text { i analizowanie przepisów Kodeksu pracy. }\end{array}$ & nie występuje \\
\hline $\begin{array}{l}\text { 9. Analizowanie otoczenia przedsiębiorstwa, w tym } \\
\text { rynku, na którym działa. }\end{array}$ & nie występuje \\
\hline $\begin{array}{l}\text { 10. Projektowanie działań w zakresie zakładania } \\
\text { własnego przedsiębiorstwa lub podejmowania } \\
\text { innych przedsięwzięć o charakterze społeczno-eko- } \\
\text { nomicznym. }\end{array}$ & nie występuje \\
\hline $\begin{array}{l}\text { 11. Przygotowanie do prowadzenia własnej działal- } \\
\text { ności gospodarczej. }\end{array}$ & nie występuje \\
\hline $\begin{array}{l}\text { 12. Efektywne uczestniczenie w pracy zespoło- } \\
\text { wej z wykorzystaniem umiejętności w zakresie } \\
\text { komunikacji interpersonalnej oraz wdrażanie zasad } \\
\text { skutecznego przywództwa w organizacji. }\end{array}$ & $\begin{array}{l}\text { [Uczeń] wykorzystuje formy komunikacji } \\
\text { werbalnej i niewerbalnej; podejmuje decy- } \\
\text { zje i ocenia ich skutki, zarówno pozytywne, } \\
\text { jak i negatywne. }\end{array}$ \\
\hline $\begin{array}{l}\text { 13. Rozpoznawanie działań etycznych i nieetycznych } \\
\text { w życiu gospodarczym oraz przejawów społecznej } \\
\text { odpowiedzialności biznesu. }\end{array}$ & $\begin{array}{l}\text { [Uczeń] wyjaśnia zasady etyczne w bizne- } \\
\text { sie i w relacjach pracownik-pracodawca, } \\
\text { potrafi ocenić zachowania pod względem } \\
\text { etycznym. }\end{array}$ \\
\hline
\end{tabular}




\section{Kształtowanie postaw.}

\begin{tabular}{|c|c|}
\hline $\begin{array}{l}\text { 1. Wykorzystanie zdobytej wiedzy ekonomicznej do } \\
\text { rozwijania własnej postawy przedsiębiorczej jako } \\
\text { jednego z podstawowych warunków aktywnego } \\
\text { uczestnictwa w życiu społeczno-gospodarczym, } \\
\text { w tym skutecznego wykonywania pracy najemnej } \\
\text { i prowadzenia własnej działalności gospodarczej. }\end{array}$ & nie występuje \\
\hline $\begin{array}{l}\text { 2. Korzystanie z szans pojawiających się na rynku, } \\
\text { podejmowanie inicjatywy, pomysłowość oraz } \\
\text { zdolność do pokonywania barier wewnętrznych } \\
\text { i zewnętrznych. }\end{array}$ & nie występuje \\
\hline $\begin{array}{l}\text { 3. Docenianie postaw przedsiębiorczych w życiu } \\
\text { codziennym, gotowość do czynnego uczestnictwa } \\
\text { w życiu społeczno-gospodarczym kraju oraz współ- } \\
\text { odpowiedzialność za jego rozwój. }\end{array}$ & nie występuje \\
\hline $\begin{array}{l}\text { 4. Docenianie roli przedsiębiorców budujących } \\
\text { w sposób odpowiedzialny konkurencyjną gospodarkę } \\
\text { oraz dostrzeganie znaczenia wolności gospodar- } \\
\text { czej i własności prywatnej jako filarów gospodarki } \\
\text { rynkowej. }\end{array}$ & nie występuje \\
\hline $\begin{array}{l}\text { 5. Przyjmowanie postaw patriotyzmu gospodarczego, } \\
\text { rozumianego jako odpowiedzialność konsumentów } \\
\text { i ludzi biznesu za dobrobyt gospodarczy i społeczny } \\
\text { kraju. }\end{array}$ & nie występuje \\
\hline $\begin{array}{l}\text { 6. Dostrzeganie konsekwencji działań nieetycz- } \\
\text { nych związanych z finansami, w tym obowiązkami } \\
\text { podatkowymi. }\end{array}$ & nie występuje \\
\hline $\begin{array}{l}\text { 7. Kształtowanie w sobie odpowiedzialnych postaw } \\
\text { jako przyszłych pracowników i pracodawców oraz } \\
\text { należytego wypełnienia obowiązków, a także } \\
\text { sprawiedliwego, opartego na prawości i dążeniu do } \\
\text { prawdy traktowania pracowników. }\end{array}$ & nie występuje \\
\hline $\begin{array}{l}\text { 8. Kształtowanie proaktywności, odpowiedzialności } \\
\text { za siebie i innych oraz umiejętnego godzenia własne- } \\
\text { go dobra z dobrem innych ludzi. }\end{array}$ & nie występuje \\
\hline $\begin{array}{l}\text { 9. Zainteresowanie prowadzeniem własnej dzia- } \\
\text { łalności gospodarczej oraz motywacja do ciągłego } \\
\text { samorozwoju i inwestowania w siebie. }\end{array}$ & nie występuje \\
\hline $\begin{array}{l}\text { 10. Kształtowanie postawy otwartości i szacunku do } \\
\text { innych osób oraz zdolności podejmowania dialogu } \\
\text { i współpracy. }\end{array}$ & nie występuje \\
\hline $\begin{array}{l}\text { 11. Przyjmowanie postaw etycznych, społecznej soli- } \\
\text { darności i odpowiedzialności w życiu gospodarczym. }\end{array}$ & nie występuje \\
\hline \multicolumn{2}{|c|}{$\begin{array}{l}\text { * tj. liceum, technikum i szkoły branżowej I stopnia (podstawa zapisana w postaci dwóch } \\
\text { rozporządzeń, jest w zakresie treści identyczna) } \\
\text { ** tj. liceum, technikum i zasadniczej szkoły zawodowej (podstawa dla szkoły zawodowej została } \\
\text { określona jako tożsama z tą do LO i technikum. }\end{array}$} \\
\hline
\end{tabular}

Źródło: Opracowanie własne na podstawie Rozporzq̨dzenie MEN (2012, 2018a,b). 
Jak widać szczególne miejsce w nowej podstawie programowej zajmuje nie tylko kształtowanie umiejętności, ale także i postaw, szczególnie tych związanych z samorozwojem, proaktywności, relacjami z innymi ludźmi, odpowiedzialności za siebie i innych, docenianiem działalności przedsiębiorców, a także postaw etycznych, solidarności i społecznej odpowiedzialności. Stanowi to nową jakość w podejściu do edukacji w zakresie przedsiębiorczości i nawiązuje do wcześniejszych postulatów w zakresie formułowania celów wychowawczych w edukacji w zakresie przedsiębiorczości (Rachwał 2005, 2017) i opinii B. Suchodolskiego (1990), że mimo fali krytyki i trudności jakie muszą pokonywać nauczyciele, nie powinni się oni wyrzekać troski o wychowanie uczniów. Wychowanie bowiem pozostaje jednym z głównych czynników kształtowania ludzi, a więc tym samym budowania przyszłości (Suchodolski 1990, Rachwał 2005).

\section{Dzialy treści nauczania w podstawie programowej dla szkół średnich}

Treści kształcenia w zakresie przedsiębiorczości zaproponowane w starej i nowej podstawie programowej wykazują pewne różnice, choć przy konstrukcji nowej podstawy programowej starano się korzystać z dotychczasowych dobrych doświadczeń. W efekcie tego nowa podstawa zawiera zapisy wymagań szczegółowych, które nawiązują wyraźnie do niektórych wcześniejszych. Układ treści jest jednak inny.

W podstawie programowej z 2012 roku wyróżniono sześć działów, zgodnie z rozporządzeniem wymagania szczegółowe podzielone zostały na sześć działów:

$\rightarrow$ Człowiek przedsiębiorczy,

$\rightarrow$ Rynek - cechy i funkcje,

$\rightarrow$ Instytucje rynkowe,

$\rightarrow$ Państwo, gospodarka,

$\rightarrow$ Przedsiębiorstwo,

$\rightarrow$ Rynek pracy.

Natomiast w nowej podstawie programowej wymagania szczegółowe, dotyczące treści kształcenia, podzielono na cztery działy (zapisując oprócz ich hasłowych nazw także treści kształcenia: 
$\rightarrow$ Gospodarka rynkowa: przedsiębiorczość w gospodarce rynkowej, gospodarka nakazowo-rozdzielcza (centralnie planowana) i rynkowa, rodzaje rynków, podmioty gospodarki rynkowej, struktury rynkowe, mechanizm rynkowy, fazy cyklu koniunkturalnego, rola państwa w gospodarce, konsument na rynku.

$\rightarrow$ Rynek finansowy: pieniądz i jego obieg, instytucje rynku finansowego, formy inwestowania, bank centralny i polityka pieniężna, bankowość komercyjna i spółdzielcza, podatki, ubezpieczenia, umowy bankowe i ubezpieczeniowe, ochrona klienta usług finansowych, etyka w finansach

$\rightarrow$ Rynek pracy: mierniki i wskaźniki, popyt i podaż na rynku pracy, kariera zawodowa, poszukiwanie pracy, rozmowa kwalifikacyjna, formy zatrudnienia, systemy płac, prawa i obowiązki pracownika i pracodawcy, bhp i organizacja pracy, Państwowa Inspekcja Pracy, związki zawodowe, etyka w pracy.

$\rightarrow$ Przedsiębiorstwo: klasyfikacje przedsiębiorstw, biznesplan, otoczenie przedsiębiorstwa, formy organizacyjno-prawne, procedury rejestracji i likwidacji, źródła finansowania działalności, analiza rynku, zarządzanie przedsiębiorstwem, praca zespołowa, marketing, wynik finansowy, formy opodatkowania, księgowość, negocjacje, etyka w biznesie i społeczna odpowiedzialność przedsiębiorstw, funkcjonowanie przedsiębiorstwa.

Analiza wymagań szczegółowych wskazuje, że w nowej podstawie programowej położono nacisk na: identyfikację zjawisk i dostrzeganie prawidłowości, dyskusję, poruszanie szerokich tematów (w tym również trudnych i kontrowersyjnych), analizowanie i interpretowanie zebranych informacji, ocenianie i dostrzegania różnych aspektów analizowanych zjawisk ekonomicznych, kształtowanie człowieka myślącego i zdolnego do merytorycznej dyskusji (który nie poddaje się manipulacyjnym przekazom z mediów i ideologicznym interpretacjom, fake-newsom itp.), umiejętność czytania ze zrozumieniem (aktów prawnych, umów, ogólnych warunków ubezpieczenia itp.), a przede wszystkim na kształtowanie postaw, szczególnie odpowiedzialności, uczciwości, otwartości i szacunku (Rachwał i in. 2018). Zauważa się też zmianę polegającą na przesunięciu nacisku z wyposażenia uczniów w wiedzę ekonomiczną na rzecz kształtowania umiejętności związanych z finansami, biznesem i zachowaniami niezbędnymi na rynku pracy. 


\section{Nowe innowacyjne treści w podstawie programowej dla szkól średnich}

Analiza nowej podstawy programowej do podstaw przedsiębiorczości pozwoliła ocenić jej zapisy pod kątem nowych innowacyjnych treści i umiejętności, które zostały wprowadzone do nowej podstawy programowej w ramach reformy edukacji w Polsce. Jednocześnie dokonano weryfikacji treści nauczania - wymagań szczegółowych, które sprzyjają przygotowaniu ucznia do nowych wyzwań, które ze sobą niesie XXI w., głównie tych związanych z budową gospodarki opartej na wiedzy i rozwojem cywilizacji informacyjnej.

W podstawie programowej pojawiło się szereg nowych zapisów, które można określić jako innowacyjne. Najwięcej treści związanym z nowoczesnymi zagadnieniami znajduje się w rozdziale czwartym nt. przedsiębiorstwa. Po pierwsze, w zapisach podstawy, podkreślane jest szczególnie to, czego nie było w dotychczasowych podstawach programowych, a mianowicie duże znaczenie innowacyjności i kreatywności. Zapisy dotyczące kreatywności dotyczą działań promocyjnych, które wedle podstawy powinny być projektowane kreatywnie (4.13), zaplanowane i pełne refleksji. Jednocześnie kreatywność, ale i innowacyjność zdaniem autorów podstawy powinna być też dostrzegana przez uczniów w ich życiu osobistym, w rozwoju społeczno-gospodarczym w skali lokalnej, regionalnej, krajowej i globalnej (1.3).

Zapisy związane z innowacyjnością odnoszą się także do planowanej w ramach zajęć z podstaw przedsiębiorczości własnej działalności gospodarczej lub przedsięwzięcia społecznego, które uczniowie powinni oceniać pod względem innowacyjności (4.3). Innym zapisem, który odwołuje do uwzględniania innowacyjności działalności przedsiębiorstwa jest ostatnie z wymagań szczegółowych, które odnosi się ćwiczeń terenowych lub spotkania z przedsiębiorcą, podczas których uczeń zobowiązany jest do analizy procesu funkcjonowania przedsiębiorstwa lub jego prowadzenia m.in. w odniesieniu do podejmowanych przez nie działaniach innowacyjnych (4.23).

Ważne zapisy dotyczące nowych zagadnień dotyczą także współczesnych form finansowania działalności gospodarczej, nie poruszanych w poprzedniej podstawie programowej. W ósmym podpunkcie dotyczącym przedsiębiorstwa (4.8) wskazano, że uczeń powinien „znajdować możliwości finansowania działalności gospodarczej lub projektowanego przedsięwzięcia (w tym ze środków instytucji finansowych, urzędów 
pracy, funduszy unijnych i venture capital, „aniołów biznesu”) oraz określać funkcje inkubatorów przedsiębiorczości w powstawaniu i rozwoju małych firm, w tym start-upów". To odwołanie do form finansowania, ale i sposobów zakładania najnowocześniejszych przedsiębiorstw, które w Polsce bardzo szybko zyskują na znaczeniu i zdaniem A. Skali (2018) stanowią także duże wyzwanie dla systemu edukacji. Przykładem może być działalność podejmowana w Krakowskim Parku Technologicznym, w którym start-upom zapewniana jest szeroka pomoc, w tym najlepszym firmom proponowane są oferty „aniołów biznesu”, którzy mogą zaoferować dostęp do dużego kapitałem międzynarodowego

Odwołanie do start-upów jest także na początku czwartego rozdziału, w punkcie pierwszym (4.1), który zobowiązuje uczniów do "klasyfikacji przedsiębiorstw według kryteriów rodzaju prowadzonej działalności, wielkości i formy własności oraz charakteryzuje innowacyjne modele biznesu, w tym start-upy". Zatem zarówno zapisy dotyczące wiedzy, jak i umiejętności odnoszą się do zupełnie nowych zagadnień, które we współczesnej gospodarcze, choć nowe, to znalazły już swoje stałe miejsce.

W podstawie programowej znajdują się także zapisy, których realizacja pozwoli młodemu człowiekowi przygotować się do funkcjonowania we współczesnym świecie. Szczególnie ważne wydają się zapisane efekty kształcenia, które wymagają od ucznia skorelowania poznanej wiedzy i umiejętności z własnym życiem. Już w pierwszym wymaganiu szczegółowym w rozdziale pierwszym znajdujemy zapis: „uczeń: identyfikuje cechy człowieka o postawie przedsiębiorczej, rozpoznaje je u siebie oraz określa związek zachowania się osoby przedsiębiorczej z szansami, jakie stwarza gospodarka rynkowa (1.1)". Podobnie w rozdziale dotyczącym rynku pracy znajdujemy odniesienie do tych ważnych umiejętności: „rozpoznaje motywy aktywności zawodowej człowieka oraz analizuje szanse i możliwości rozwoju własnej kariery zawodowej, dostrzegając rolę procesu uczenia się przez całe życie" (3.3).

Podkreślana jest także umiejętność samodzielnego myślenia, która jest także ważna w natłoku różnych informacji trafiających do człowieka różnymi kanałami przekazu, np. „uczeń: ocenia wady i zalety poszczególnych form opodatkowania indywidualnej działalności gospodarczej w zakresie podatku dochodowego (...)" (4.15). Ponadto uwydatniona jest potrzeba uczenia się poprzez bliskie uczniowi przykłady, np. „wyszukuje i analizuje informacje o sukcesach polskich przedsiębiorstw, w tym ze 
swojego regionu, na rynku krajowym i międzynarodowym, osiąganych zgodnie z prawem i etyką biznesu" (4.22), gdyż takie przykłady wydają się dla ucznia bliższe i możliwe do głębszego poznania i zrozumienia ponieważ pochodzą z najbliższego otoczenia.

\section{Podsumowanie}

Należy stwierdzić, że nowa podstawa programowa podstaw przedsiębiorczości do szkół średnich stanowi próbę odpowiedzi na współczesne wyzwania cywilizacyjne i powinna przyczynić się do lepszego przygotowania ich do realizacji celów w życiu osobistym i zawodowym, w tym wykonywania pracy najemnej i samozatrudnienia. Położone większy nacisk na cele ogólne w zakresie rozwijania umiejętności i kształtowania postaw. Rozszerzone zostały w niej treści kształcenia związane z pracą i funkcjonowaniem przedsiębiorstwa (w tym zakładaniem swojego biznesu), dla których podbudową jest wcześniej realizowana problematyka ekonomiczna i finansowa. Nowa podstawa programowa wprowadza także szereg zagadnień, które dotychczas nie występowały w tym fundamentalnym dokumencie. Wprowadzenie innowacyjnych treści kształcenia w zakresie wiedzy i umiejętności, a także postaw należy uznać za konieczność. Podstawa programowa powinna wrowadzać w ten sposób zagadnienia nowe, które są konieczne, aby przygotować ucznia do wyzwań współczesnego świata. Takie podejście znalazło swoje odzwierciedlenie w zapisach podstawy. Kluczową rolę w jej realizacji odgrywa jednak nauczyciel, dlatego problematyka ta wymaga dalszych badań nad wdrażaniem zapisów podstawy w praktyce szkolnej. Czas pokaże w jakim stopniu jest ona wdrażana. 


\section{Bibliografia}

$\rightarrow$ Andrzejczyk, A. (2016), Metody badań edukacji przedsiębiorczej [w:] „Przedsiębiorczość - Edukacja", nr 12, s. 352-363.

$\rightarrow$ Bartoń, M., 2005, Przedsiębiorczość jako przedmiot matury 2008 [w:] „Przedsiębiorczość - Edukacja", nr 1, s. 255-258.

$\rightarrow$ Borowiec, M., Rachwał, T. (2011), Kształtowanie postaw przedsiębiorczych na lekcjach geografii wyzwaniem edukacyjnym w procesach globalizacji [w:] „Przedsiębiorczość - Edukacja”, nr 7, s. 321-332.

$\rightarrow$ Borowiec-Gabryś, M., Kilar, W., Rachwał, T. (2018), Przedsiębiorczość jako kompetencja przyszłości [w:] S. Kwiatkowski (red.), Kompetencje przyszłości, Warszawa: FRSE, s. 68-89.

$\rightarrow$ Brzozowski, T., (2013), Status przedsiębiorczości w warunkach kryzysu edukacji [w:] „Przedsiębiorczość - Edukacja”, nr 9, s. 258-272.

$\rightarrow$ Czechowski, J. (2014), Przedsiębiorczy nauczyciel jako skuteczny wychowawca [w:] „Horyzonty Wychowania", nr 13(26), s. 145-163.

$\rightarrow$ Gaweł, A. (2014), Gry strategiczne w edukacji przedsiębiorczej [w:] „Horyzonty Wychowania", nr 13(26), s. 303-325.

$\rightarrow$ Górz, B., Rachwał T. (2006), Uwagi do projektu zmiany podstawy programowej podstaw przedsiębiorczości (zrealizowanej przez Instytut Spraw Publicznych na zlecenie Ministerstwa Edukacji Narodowej) [w:] „Horyzonty Wychowania”, nr 2, s. 226-235.

$\rightarrow$ Kalita, B. (2014), Przedsiębiorczość jako kompetencja kluczowa w procesie uczenia się przez całe życie [w:] „Zeszyty Naukowe Politechniki Śląskiej. Organizacja i Zarządzanie", nr 72, s. 51-64.

$\rightarrow$ Kawecki, Z. (2005), Ranga przedmiotu podstawy przedsiębiorczości w edukacji szkolnej [w:] „Przedsiębiorczość - Edukacja”, nr 1, s. 203-206.

$\rightarrow$ Kilar, W., Kurek, S., Rachwał, T., Semczuk, M., Świętek, A. (2016), Kształtowanie postaw przedsiębiorczych z uwzględnieniem zasad ekorozwoju wśród uczniów 
z wykorzystaniem gry PowerPlayer wypracowanej w ramach projektu SUSEN [w:] „Przedsiębiorczość - Edukacja”, nr 12, s, 444-456.

$\rightarrow$ Kompetencje kluczowe. Realizacja koncepcji na poziomie szkolnictwa obowiq̨zkowego (2005), Warszawa: Eurydice, Fundacja Rozwoju Systemu Edukacji. Kulikowska, M., Krasnodębska, B. (2007), Techniki multimedialne w nauczaniu podstaw przedsiębiorczości [w:] „Przedsiębiorczość - Edukacja”, nr 3, s. 308$-316$.

$\rightarrow$ Łazowska, E. (2005), Metodyka nauczania podstaw przedsiębiorczości i podstaw ekonomii [w:] „Przedsiębiorczość - Edukacja”, nr 1, Kraków, s. 251-254.

$\rightarrow$ Osuch, E., Osuch W. (2006), Przedmiot podstawy przedsiębiorczości w opinii uczniów i rodziców na przykładzie wybranych krakowskich szkół [w:] „Przedsiębiorczość - Edukacja", nr 1, s. 195-202.

$\rightarrow$ Osuch, W. (2012), Podstawy przedsiębiorczości w opinii uczniów krakowskich liceów-szanse i oczekiwania. [w:] „Przedsiębiorczość - Edukacja”, nr 8, 37-47.

$\rightarrow$ Piróg, D. (2015), Kompetencje z zakresu przedsiębiorczości: rozważania teoretyczne i ich ilustracje w obszarze szkolnictwa wyższego [w:] „Przedsiębiorczość - Edukacja", nr 11, 364-376.

$\rightarrow$ Rachwał, T. (2017), Entrepreneurship in School in the Conditions of the Education System Reform in Poland - a Voice in the Discussion on the Directions of Change [w:] „Przedsiębiorczość -Edukacja”, nr 13, s. 330-339.

$\rightarrow$ Rachwał, T. (2006), Kształtowanie postaw przedsiębiorczych w edukacji szkolnej [w:] B. Muchacka (red.), Szkoła w nauce i praktyce edukacyjnej, t.II, Kraków: Oficyna Wydawnicza "Impuls", Akademia Pedagogiczna w Krakowie, s.427-434.

$\rightarrow$ Rachwał, T., Kurek, S., Boguś, M. (2016), Entrepreneurship Education at Secondary Level in Transition Economies: A Case of Poland [w:] "Entrepreneurial Business and Economics Review", 4(1), s. 61-81.

$\rightarrow$ Rachwał, T. (2004), Cele i treści kształcenia przedsiębiorczości w szkołach ponadgimnazjalnych. [w:] J. Brdulak, M. Kulikowski (red.), Przedsiębiorczość stymulatorem rozwoju gospodarczego, Warszawa: Instytut Wiedzy, s. 263-270.

$\rightarrow$ Rachwał, T. (2005), Kształtowanie postaw u uczniów na lekcjach przedsiębiorczości [w:] „Przedsiębiorczość - Edukacja”, nr 1, s. 137-144.

$\rightarrow$ Rachwał, T. (2009), Ocena projektu zmian podstawy programowej podstaw przedsiębiorczości (przedstawionej przez MEN w 2008 r. w ramach reformy systemu edukacji) [w:] „Przedsiębiorczość - Edukacja”, nr 5, s. 349-372.

$\rightarrow$ Rachwał, T., Kilar, W., Kawecki, Z., Wróbel, P. (2018), Edukacja w zakresie przedsiębiorczości w wychowaniu przedszkolnym, szkole podstawowej i szkołach średnich w świetle nowej podstawy programowej [w: „Przedsiębiorczość - Edukacja", nr 14, s. 389-424. 
$\rightarrow$ Rachwał, T., Kudełko, J., Tracz, M., Wach, K., Kilar, W. (2008), Projekt podstawy programowej podstaw przedsiębiorczości w zakresie rozszerzonym dla liceum ogólnokształcącego, liceum profilowanego i technikum [w:] „Przedsiębiorczość - Edukacja", nr 4, s. 322-334.

$\rightarrow$ Rozporzq̨dzenie Ministra Edukacji Narodowej z dnia 26 lipca 2018 r. zmieniajace rozporządzenie w sprawie podstawy programowej wychowania przedszkolnego oraz podstawy programowej kształcenia ogólnego dla szkoły podstawowej, w tym dla uczniów z niepełnosprawnościq intelektualng $w$ stopniu umiarkowanym lub znacznym, kształcenia ogólnego dla branżowej szkoły I stopnia, kształcenia ogólnego dla szkoły specjalnej przysposabiającej do pracy oraz kształcenia ogólnego dla szkoły policealnej, 2018b (Dz.U. 2018, poz. 1679).

$\rightarrow$ Rozporzq̨dzenie Ministra Edukacji Narodowej z dnia 27 sierpnia 2012 r. w sprawie podstawy programowej wychowania przedszkolnego oraz kształcenia ogólnego w poszczególnych typach szkół (Dz.U. 2012, poz. 977).

$\rightarrow$ Rozporzq̨dzenie Ministra Edukacji Narodowej z dnia 28 marca 2017 r. w sprawie ramowych planów nauczania dla publicznych szkół (Dz.U. 2017, poz. 703).

$\rightarrow$ Rozporzqdzenie Ministra Edukacji Narodowej z dnia 30 stycznia 2018 r. w sprawie podstawy programowej kształcenia ogólnego dla liceum ogólnokształcącego, technikum oraz branżowej szkoły Il stopnia, 2018a (Dz.U. 2018, poz. 467).

$\rightarrow$ Skala, A. (2018), Startupy. Wyzwanie dla zarzq̨dzania i edukacji przedsiębiorczości, Kraków-Legionowo: edu-Libri.

$\rightarrow$ Sowislok, K. (2012), Przedsiębiorczość w szkole ponadgimnazjalnej na przykładzie II Liceum Ogólnokształcq̨cego w Zabrzu [w:] „Przedsiębiorczość - Edukacja", nr 8, 57-63.

$\rightarrow$ Suchodolski, B., 1990, Wychowanie mimo wszystko, Warszawa: WSiP.

$\rightarrow$ Szkurłat E., Hibszer A., Piotrowska I., Rachwał T. (2018), Podstawa programowa geografii źródłem nauczycielskich wyzwań [w:] Adam Hibszer, Elżbieta Szkurłat (red.), Nauczyciel geografii wobec wyzwań reformowanej szkoły, Seria: Prace Komisji Edukacji Geograficznej Polskiego Towarzystwa Geograficznego, t. 8, Sosnowiec: Komisja Edukacji Geograficznej PTG, s. 13-31.

$\rightarrow$ Śrutowska, D., 2006, Wykorzystanie multimediów w nauczaniu przedsiębiorczości [w:] „Przedsiębiorczość - Edukacja”, nr 2, s. 264-278.

$\rightarrow$ Tracz, M. (2005), O niektórych kryteriach doboru treści nauczania do podstawy programowej i programu nauczania z podstaw przedsiębiorczości [w:] „Przedsiębiorczość - Edukacja", nr 1, s. 207-21.

$\rightarrow$ Tracz, M. (2006), Rola i znaczenie podstaw przedsiębiorczości w kształceniu ogólnym [w:] „Przedsiębiorczość - Edukacja”, nr 2, s. 222-22. 
$\rightarrow$ Tracz, M. (2015), Przedmiot podstawy przedsiębiorczości w opinii uczniów i nauczycieli - studium porównawcze [w:] „Przedsiębiorczość - Edukacja”, nr 11, s. 391-400.

$\rightarrow$ Tracz, M., Rachwał, T. (2007), Przedmiot podstawy przedsiębiorczości - założenia realizacji a przygotowanie nauczycieli [w:] „Przedsiębiorczość-Edukacja”, nr 3, s. 286-296.

$\rightarrow$ Tracz, M., Rachwał, T. (2008), Metody nauczania i środki dydaktyczne stosowane przez nauczycieli podstaw przedsiębiorczości - wyniki badań [w:] „Przedsiębiorczość - Edukacja", nr 4, s. 335-340.

$\rightarrow$ Wach, K. (2012), Kształtowanie postaw przedsiębiorczych w programach nauczania. Stan obecny i proponowane kierunki zmian [w:] P. Wachowiak, M. Dąbrowski, B. Majewski (red.), Kształtowanie postaw przedsiębiorczych a edukacja ekonomiczna, Warszawa: Fundacja Promocji i Akredytacji Kierunków Ekonomicznych, s. 120-127

$\rightarrow$ Wach, K. (2013), Edukacja na rzecz przedsiębiorczości wobec współczesnych wyzwań cywilizacyjno-gospodarczych [w:] „Przedsiębiorczość- Edukacja”, nr 9, s. 246-257.

$\rightarrow$ Wach, K. (2014), Edukacja dla przedsiębiorczości: pomiędzy przedsiębiorczq pedagogikq a edukacjq ekonomicznq i biznesowq [w:] "Horyzonty Wychowania”, nr 13(28), s. 11-31.

$\rightarrow$ Wach, K. (2016), Edukacja przedsiębiorcza: analiza bibliometryczna polskiego piśmiennictwa. Horyzonty Wychowania, 15(34), s. 11-26.

$\rightarrow$ Ziółkowska-Weiss, K. (2014), Problematyka podstaw przedsiębiorczości w opinii uczniów szkoły ponadgimnazjalnej. Przydatność w życiu czy konieczność nauki? [w:] „Przedsiębiorczość - Edukacja”, nr 10, s. 366-377.

$\rightarrow$ Ziółkowska-Weiss, K. (2016), Ocena nauczania podstaw przedsiębiorczości przez uczniów liceum ogólnokształcq̨cego [w:] „Przedsiębiorczość - Edukacja”, nr 12, s. 457-47.

$\rightarrow$ Żur, A. (2014), Exploring the Role of Inspiration in Entrepreneurship Education [w:] „Horyzonty Wychowania", nr 13(26), s. 179-194. 